огляди

\title{
Plant sulfolipid. III. Role in adaptation
}

\author{
O. I. Kosyk, A. A. Okanenko, N. Yu. Taran
}

National Taras Shevchenko University of Kyiv

64, Volodymyrska Str, Kyiv, Ukraine, 01033

a_okanenko@yahoo.co.uk

\begin{abstract}
The quality and/or relative content of plant sulfoquinovosyl diacylglycerol (SQDG) change in response to a stress action. Various types of stress action induce two types of response-more general to the oxidative stress and specific - to a concrete stress factor. Besides, two types of reaction take place in photosynthesizing and non-photosynthesizing tissues. SQDG molecules take part in the adaptation reaction being cytochrome oxidase, $C F_{1}, F_{1}$, ATPase regulators, protectors and stabilizing agents for $D_{1} / D_{2}$ dimers and LHC II. This compound in non-photosynthesising tissues could be connected with negative charge domination required for lipoprotein complex stabilisation. SQDG quantitative changes and acyl composition shifts take place at both abiotic and biotic factors impact.
\end{abstract}

Keywords: sulfolipid, sulfoquinovosyl diacylglycerol, stress.

In response to environmental stresses, living organisms acquired the capability of recognizing such stresses and adapting themselves to various types of stress during evolution. Stress affects many physiological processes including protein and lipid metabolism and enzyme activity [1-5]. Since lipids are major components of membranes and are influenced considerably by environmental factors $[6,7]$ overall plant growth and development will be affected by significant changes in lipid metabolism. The results of studies devoted to lipid involvement in adaptation processes show that both sulfoquinovosyl diacylglycerol (SQDG) quantitative changes and fatty acid composition shifts take place.

Oxidative stress. The questions of specificity of plant adaptive reaction to the environment unfavorable factor action are bound mainly with the oxidation stress. Abiotic and biotic stresses can cause in plants secondary oxidation stress. Plenty of oxygen and

(C) Інститут молекулярної біології і генетики НАН України, 2009 highly power reactions of electron transfer associated with the thylacoid membranes are the main source of highly active oxygen intermediators in photosynthesizing tissues of plants. Anion of superoxide of $\mathrm{O}_{2}{ }^{-}$or a free oxygen radical is generated when electrons of PS II are accepted by $\mathrm{O}_{2}$ instead of feredoxine and is transformed with participation of SOD usually in $\mathrm{H}_{2} \mathrm{O}_{2}$ or sometimes in highly toxic free radical $\mathrm{OH}$ via Fe-catalyzed Haber-Weiss reaction [8]. Action of abiotic and biotic stresses causes growth of maintenance of highly active oxygen derivates. Superoxides are the charged molecules and can not pass via biological membranes.

Therefore subcellular compartmentation of protective mechanisms is critical for elimination of superoxide ions in the places of their origin in cells [9]. Oxygen radical action upon isolated membranes caused an inccrease in their viscosity and permeability, in temperature of lipid phase transition, lipid phosphorus liberation and piling up free fatty acids 
[10]. In general the mechanism of attack of free radicals is known to include the oxidation of acyl chains [11], but it is not excluded, that free radicals can cause the reactions of de-etherification of polar lipids and liberation of fat acids which can be easily oxidized [12]. Bearing in mind that the oxidative stress accompanies many other stresses of plants, any changes in the lipid composition caused under such circumstances are of special significance.

A few data available evidence that oxidative processes induced by a high concentration of ozone run in two phases. During the first phase ( 8 hours) a loss of pigments and lipids (mainly MGDG with some DGDG) was observed. The loss in chloroplast lipids is accompanied by a small increase in the malondialdehyde (MDA), TAG and DAG content. The second phase of oxidative injury is characterized by a massive destruction of pigments and begins with a drastic fall in MGDG and a smaller decrease in DGDG and PC contents which are accompanied by significant increases in TAG, DAG and MDA [13]. However, the anionic lipid (SQDG and PI) content was stable for the period of ozone exposure (in spinach leaves, at least). Similar lipid changes were also observed in several plant species, and in broad bean leaves, a relative increase in SQDG took place. Because both galactolipids were significantly destroyed during ozone exposure, the SQDG content expressed as mol\% of the total glycolipids increased up to 45 (depending on a species) [14, 15]. Interesting results were obtained with a sulfoglycolipidic fraction isolated from the red microalga Porphyridium cruentum. It was demonstrated that sulfolipid contained large amounts of palmitic acid (26.1\%), arachidonic acid (C20:4n-6, 36.8\%), eicosapentaenoic (C20:5n-3, $16.6 \%$ ) acids and 16:1n-9 fatty acid $(10.5 \%)$ and strongly inhibited the production of superoxide anion generated by peritoneal leukocytes [16]. Our experiments with the induced oxidative stress showed that hydrogen peroxide affect pigment and glycolipid composition with increasing lipid peroxidation activity in dose and time dependent manner. The treatment with various hydrogen peroxide concentration caused significant SQDG content increase in all variants. The results of field experiments showed a drastic fall of SQDG level in 24 hours (h) with a subsequent significant lipid accumulation. This compound quantity was stable after the second treatment when light MGDG decrease was noted and DGDG level was stable during the whole experiment [17]. Concerning the meaning of these changes the idea seems acceptable that this lipid may also provide a source of cysteine under the conditions of oxidative stress [18]. It functions as a component in the sulfur cycle in plants and is rapidly metabolized for protein production under the conditions of sulfur depletion [19]. Thus the additionary quantity of thiol group needed at oxidative agent action can be supplied.

Irradiation level. The quantity of the light in natural environments can vary over several orders of magnitude and on a time scale that ranges from seconds to seasons. Plant acclimation to light intensity depends upon the structure and function of the photosynthetic apparatus. The photosystems and their subcomplexes (LHCs, $\mathrm{D}_{1}, \mathrm{D}_{2}$ ) are anchored within the thylakoid membrane through the lipids. This close connection between lipids and photosystem subcomplexes indicate an interdependence between both, which supports the concept of photosynthesis regulation by changes in the thylakoid membrane structure or the entire chloroplast [20]. Besides, it was said earlier that the cells of Chlamydomonas SQDG-deficient mutant tended to suffer from photoinhibition [21]. The data available indicate that the red alga Tichocarpus crinitus exposed to low light (10\% of the incident photosynthetically active radiation) conditions accumulated the only SQDG content characterized by palmitooleic (hexadecenoic, 16:1) acid 20-fold increase with small content deviation of the other FA residues [22]. But Antarctic sea ice diatoms (the algal composition in the culture was $66 \pm$ $\pm 11 \%$ of Navicula gelida var. antarctica, $20 \pm 7 \%$ of Fragilariopsis curta and $14 \pm 9 \%$ of Nitzschia medioconstricta) did not show any difference in SQDG content at two different photon flux densities $-15.0 \pm$ $\pm 5.0 \mu \mathrm{mol}$ photons $\mathrm{m}^{-2} \cdot \mathrm{s}^{-1}$ and photon flux density of $2.0 \pm 1.0 \mu \mathrm{mol}$ photons $\mathrm{m}^{-2} \mathrm{~s}^{-1}$. The main difference was palmitic residue decrease accompanied by stearic (18:0) and eicosapentaenoic acid (20:5n-3) twice increase [20]. The authors considered the increase in photon trapping and an increase in electron transport velocity at PS II under $2 \mu \mathrm{mol}$ photons $\mathrm{m}^{-2} \cdot \mathrm{s}^{-1}$ between bound $\mathrm{Q}_{\mathrm{A}}$ and $\mathrm{Q}_{\mathrm{B}}$ as a consequence of increasing $\mathrm{FA}$ desaturation of typical chloroplast lipids (MGDG, 
SQDG, PG), particular by increasing 20:5 n-3 of MGDG and SQDG. It supports the $\mathrm{Q}_{\mathrm{A}}$ and $\mathrm{Q}_{\mathrm{B}}$ interactions and thus the velocity of electron flow.

Thermoresistance. Many studies on the lipid changes caused by temperature have been made with cyanobacteria because these prokaryotic organisms are homogeneous in culture and respond very quickly to the temperature shifts. The experiments performed showed that a temperature decrease caused an increase in the SQDG content or did not affected it. For example, in Anacystis nidulans an increase in MGDG and SQDG and a decrease in DGDG were observed. Almost all of the palmitate at the $s n-1$ position of SQDG was converted to palmitoleate at low growth temperatures [23-25]. In the cyanobacterium Spirulina platensis cultivated at 35,30 and $27^{\circ} \mathrm{C}$ the low temperatures caused the SQDG content increase accompanied by the desaturation of palmitate at the $s n-2$ position of SQDG [26]. On the other hand, for Anabaena variabilis growing at low temperatures, the level of SQDG was stable with only a small conversion of palmitate to palmitoleate [23-25]. Low temperatures also induced similar effect in the higher plant lipid compositions. Our earlier investigations showed that, during autumn hardening, SQDG accumulation took place in one-year-old apple shoot bark and wood (!) and was especially striking for a hardy apple specie (Malus boccata Borh) [27]. Oquist [28] found a 2-fold increase in the SQDG content in pine thylakoid preparations during the autumn which remained high during the winter and then lowered in spring. SQDG from pine in the winter was enriched in linoleate whereas palmitate was dominant in the summer.

The results available in literature indicate that superoptimal temperatures cause an increase of SQDG content in most plants studied. For example, Atriplex lentiformis plants grown in coastal and desert regions accumulated SQDG (by $260 \%$ and $64 \%$ respectively) at high growth temperatures [1]. When Nerium oleander was grown at $45{ }^{\circ} \mathrm{C}$ rather than $20{ }^{\circ} \mathrm{C}$ the main changes in molecular species were an increase in the proportion of dipalmitoyl-SQDG from 12 up to $20 \%$ and a decrease in that of linolenoyl-palmitoyl SQDG from 40 to $30 \%$ at the higher growth temperature. At the same time the phase transition temperature increased from $19 \pm 3{ }^{\circ} \mathrm{C}$ to $24 \pm 3{ }^{\circ} \mathrm{C}$. Taking into ac- count the fact that dipalmitoyl-SQDG undergoes a transition at $42{ }^{\circ} \mathrm{C}$, it was suggested that this molecular species could be a major lipid component involved in a phase transitions in the thylakoid polar lipids [29]. Our data showed that growth at high temperature induced sulfolipid accumulation but only in the wheat leaves and chloroplasts of drought resistant varieties. In contrast, in the only sensitive species (Myronivska 808) there was a decrease in the SQDG content. The heating at temperatures 40,45 and $50{ }^{\circ} \mathrm{C}$ caused the SQDG content changes in chloroplasts described by curve with one apex at $45^{\circ} \mathrm{C}$ with following drop at $50{ }^{\circ} \mathrm{C}$ in all resistant plants [30].

The exploration of physical properties of the SQDG showed that only in sponge cucumber did phase separation begin at $15^{\circ} \mathrm{C}$ for SQDG. Nevertheless, SQDG from the chilling sensitive species contained up to three times more stearic acid than resistant plants [31]. Furthermore, Kenrick and Bishop [32] concluded that if the primary event in chilling sensitivity of higher plants is a phase transition in bulk chloroplast membrane lipids, then not only PG, but also SQDG might be involved. In particular, the main difference between Carica papaya (tropical origin) and $C$. pubescens (adapted to temperate climates) was in their SQDG species ( $57 \%$ and $36 \%$ saturated, respectively), and not in PG. Their results showed that linolenic acid residue was abundant in SQDG from the chilling-tolerant species whereas palmitate was a major component in the temperature-sensitive plants.

Water deficit. Water deficit affected the SQDG amounts in wheat depending upon wheat variety drought resistance. Our data showed that water deficit induced some SQDG accumulation in drought resistant wheat plants and the drastic decrease of it content in sensitive plants [33]. Similar results were presented by Quartacci et al. [2]. So, thylakoids of tolerant wheat variety were characterized by SQDG accumulation whereas sensitive varieties loosed it. Palmitic residue content increased while palmitooleic and linolenic ones decreased in tolerant plant SQDG whereas palmitic residue level diminished and linolenic enlarged in soft one. Thus, the SQDG accumulation in tolerant plants with a parallel rise in saturation was observed while changes in sensitive plants were exactly the opposite. Field experiments with artificial irriga- 
tion (conferred as «control») during drought showed an increase in SQDG at two stages of development (the stage of stooling and the stage of milk ripeness) for wheat exposed to drought (by 73.7 and $51.1 \%$ respectively) [34]. Similar data were obtained by Pancratova and Karimova [35] when they exposed rye to drought. Combine action of heat and water deficit induced the SQDG accumulation in the almost all resistant plant chloroplasts, whereas the SQDG content decreased in sensitive variety more drastically than in the cases of single factor action [36]. Thus the shifts observed at the heat are similar to those under the water deficit action and their combine effect induced the SQDG accumulation sometimes much more significant than when single factor action. The importance of SQDG was also indicated from experiments on rehydration of air-dried cells of the desiccation-tolerant filamentous cyanobacterium Nostoc commune. The radiolabeled pool sizes of PG and SQDG reached steady-state within several minutes, whereas the two abundant membrane glycolipids, MGDG and DGDG, achieved uniform labeling only within $2 \mathrm{~h}$ [37]. This rapid response may be connected with the ability of this cyanobacterium to tolerate desiccation.

Salinity stress. Higher plant Calystegia soldanella R. Br. (Convolvulaceae) - a halophyte plant that can grow in some areas along the Black Sea where the soil may contain up to $700-900 \mathrm{mg}$ salts in $100 \mathrm{~g}$ soil. The main glycolipid was SQDG (31.7\%) with almost equal content of MGDG (11.1\%) and DGDG (14.3\%). Contrary to the other halophyte plants from the same region, the content of phospholipids is relatively low [38].

Adaptation of the plant cells to high salinity involves osmotic adjustment and the compartmentation of toxic ions, whereas an increasing body of evidence suggests that high salinity also induces oxidative stress [39-43]. Several laboratories have reported that salinity impairs photosynthetic activity in a number of photosynthetic organisms $[44,45]$ and affect lipid composition.

Early results showed that the SQDG content was stable (relative to chlorophyll) during adaptation of barley seedlings to high concentrations of sodium chloride while the MGDG content of thylakoid membranes decreased considerably. The latter decrease meant that the relative percentage of SQDG compared to total thylakoid lipids increased by $30 \%$ [46]. In wheat roots, increased salt levels (calcium sulfate) resulted in higher (two-fold increase) levels of SQDG, while the reverse occurred in lipids from oat roots [47]. It may be interesting to note in this connection (and in view of the possible involvement of SQDG in ATPase activity) that $\mathrm{Ca}^{2+}$ activation (via annexin) of the root ATPase is important in wheat [48] whereas in oat roots the ATPase activity is mainly increased by $\mathrm{Mg}^{2+}$. However, treatment of sugar beet with sodium sulphate did not confirm the suggestion that SQDG was involved in salt-adaptation [49]. On the other hand, SQDG ranged from 5 in spinach to 20 molecules in the halotolerant alga Dunaliella salina per $\mathrm{CF}_{0}-\mathrm{CF}_{1}$ ATPase complex and this lipid could not be readily exchanged [50]. Growth of Synechococcus 6311 in the presence of $0.5 \mathrm{M} \mathrm{NaCl}$ is accompanied by significant changes in both thylakoid and cytoplasmic membrane lipid composition. MGDG content decreased while DGDG quantity raised. The total content of anionic lipids (PG and SQDG) was always higher in the isolated membranes and the whole cells from high salt-grown cultures. The observed changes in membrane fatty acids and lipids composition correlate with the alterations in electron and ion transport activities, and it is concluded that the rearrangement of the membrane lipid environment is an essential part of the process by which cells control membrane function and stability [51]. And it should be kept in mind that in extreme halophiles (Halobacterium cutirubrum, Haloferax volcanii T., Planococcus H8) polar lipid extracts contained near $14 \%$ sulfated glycolipids and that lipids extracted from the crystallizer ponds of the salterns of Margherita di Savoia (Italy) and Eilat (Israel) and from cultures of representative species of the Halobacteriaceae showed that a sulfated diglycosyl diether was the major glycolipid detected in the biomass of both salterns [52].

Results obtained by Zhang et al. [53] showed that transgenic Brassica napus plants overexpressing AtNHX1, a vacuolar $\mathrm{Na}^{+} / \mathrm{H}^{+}$antiport from Arabidopsis thaliana, were able to grow, flower, and produce seeds in the presence of $200 \mathrm{mM}$ sodium chloride. The data suggest that the major structural lipids of the extraplastidic compartments (PC and $\mathrm{PE}$ ) and of the chloroplasts (DGDG and MGDG) were unaffected by the overexpression of $A t N H X 1$ and by the growth of the 
transgenic plants at high salinity. Some differences, however, were seen in the minor chloroplastic lipids, SQDG and PG in $200 \mathrm{mM} \mathrm{NaCl}$. Although the 16/18C ratios were the same, there was lesser unsaturation of the 18C fatty acids in both SQDG and PG from transgenic plants grown in $200 \mathrm{mM} \mathrm{NaCl}$. SQDG expressed as $\mathrm{mol} \%$ of four major chloroplast lipids (MGDG, DGDG, SQDG and PG) in the case of the overexpression of AtNHXI, a vacuolar $\mathrm{Na}^{+} / \mathrm{H}^{+}$antiport from $A$. thaliana, overpassed wild type (at $10 \mathrm{mM}$ $\mathrm{NaCl}$ ) by $31 \%$ at $10 \mathrm{mM} \mathrm{NaCl}$ and by $58 \%$ at $200 \mathrm{mM}$ $\mathrm{NaCl}$. This phenomenon allows us to suppose SQDG to take part in the $\mathrm{Na}^{+} / \mathrm{H}^{+}$antiport functioning (perhaps as ATPase stabilizing agent).

The study of different $\mathrm{NaCl}$ concentration effect upon halophytes and a glycophyte showed that in the halophyte Aster tripolium the SQDG contents increased in dose-depending manner [54]. The differences in SQDG contents between the control, 258 and $517 \mathrm{mM} \mathrm{NaCl}$ in the watering solution were already substantiated after one day and change unsignificantly for 10 days of experiment. The increase in SQDG in Aster treated with high salt correlated positively with the increase in chlorophyll contents. The largest differences were observed on the $7^{\text {th }}$ day of the treatment. In roots of the same Aster plants the sulfolipid contents are about $5 \times$ lower than in Aster leaves and increased in roots of salt treated plants especially distinctly on the $5^{\text {th }}$ day.

The sulfolipid content of the other the halophyte Sesuvium portulacastrum was also higher in the leaves of plants treated with $\mathrm{NaCl}$ when compared to the non-treated plants. SQDG contained predominantly palmitic acid and $\gamma$-linolenic acid, and lesser amounts of linoleic acid and common tend was $\gamma$-linolenic acid decrease. In Sesuvium after 7 days of salt treatment the 18:2 species clearly increased in comparison to the control in a similar way as in Aster. Main SQDG molecular species in the halophytes were palmitoyl-linolenoyl (16:0/18:3) and dilinolenoyl (18:3/18:3) forms. ATPase activity study showed that F-ATPase localized in chloroplast and mitochondria increased it correlated to $\mathrm{NaCl}$ concentrations in the growth medium in Aster and, in less extent, Sesuvium. This phenomenon was accompanied by significant increase of SQDG content in Aster and Sesuvium. To confirm the results similar investigation was carried out in Thellungiella halophila, a salt tolerant relative of Arabidopsis and in Arabidopsis itself. In Thellungiella SQDG content increased due to the effect of $\mathrm{NaCl}$ echoing the result of Aster and Sesuvium, but no significant changes could be observed in Arabidopsis [54-56]. These results confirmed the suggestion that sulfolipids stabilize and/or activate F-ATPases.

Thus, taking into account that plenty of metabolic processes and adaptative reactions flow engaging ATPases, one could suppose the size of SQDG involvement in these processes. Authors concerned this SQDG increase supposed that this lipid is involved in stabilization of ATPase complexes and PS II - Aster F-ATPase activity increased with increasing $\mathrm{NaCl}$ concentration in the medium of growth [55] and might also play a role in signalling processes.

Our experiments [57] revealed that SQDG accumulation in euhalophyte Salicornia europaea L. and crinohalophyte Halimione pedunculata L. was possibly connected with its ability to accumulate high concentrations of salts $(\mathrm{NaCl})$ in its tissues. In contrast, SQDG levels were stable in Artemisia arenaria DC during changes in osmotic pressure caused by photoassimilate accumulation and decreased in Atriplex pedunculata during the elimination of salts from this organism. Hence, any involvement of SQDG in salt adaptation seems to be dependent upon the various mechanisms of salt tolerance used by different organisms.

Thus, SQDG role in this case should be considered in following directions: as compound closely connected with photophosphorylation coupling factor and ATPase stabilizing energy supply for antioxidative activity and $\mathrm{Na}^{+} / \mathrm{H}^{+}$antiport functioning; as compound neutralizing cation excess and capturing extra water.

Heavy metal action. The quantity of heavy metals in soil is often increased greatly in industrial areas and, when they are taken up by plants, they can induce both toxic and adaptive responses. There are a few studies confirms that lipid composition can be affected [58]. Cadmium exposure induced a decrease in MGDG and SQDG contents in B. napus leaves which was accompanied by a sharp increase in extra-chloroplastic lipids (PC and PI) [59]. Our results [60] showed that lead, supplied at various concentrations to hydroponic cul- 
tures, caused a decrease in SQDG in wheat seedling leaves and roots. Thus, most heavy metals tested cause a decrease of SQDG content. Concerning the phenomenon observed we can assume, that this lipid being strong anion can create complex compound with lead atom (we observed it in vitro at least). It is possible competitive usage of sulfur for sulfur containing cys-rich peptides (phytochelatins) and protein synthesis (judging on increasing protein content) according to the suggestion that the cells utilize sulfur preferentially for the synthesis of essential metabolites, such as proteins, rather than for SQDG synthesis [61]. But information presented allows also to suggest that metabolism changes induced by lead depend upon plant species and conditions of metal action. For example, while acute exposure of the moss, Rhytidiadelphus squarrosus, to low levels (1-10 mM) of lead nitrate did not change the radiolabelling of SQDG significantly, populations gathered from lead-polluted soils showed more labeling of chloroplast lipids than moss from unpolluted areas. It was considered the increased metabolism of chloroplast lipids in moss from lead-polluted regions may represent an adaptive response. Thus, the membrane lipids, damaged as a result of heavy metal pollution, could be replaced and any detrimental effect on photosynthesis being minimized [62].

Mechanical injury. Plants react to wounding, either mechanical or caused by herbivore feeding, by activating the transcription of a set of genes, the function of which is mainly devoted to wound healing and the prevention of any subsequent pathogen attack. On the other hand it is known that wounding induce ROS and $\mathrm{H}_{2} \mathrm{O}_{2}$ forming [63] following by lipid composition change reactions [15]. Our data showed that wounding (cutting the leaf apex) induce increase ( $\approx$ on $20 \%$ ) both leaf galactolipids in $4 \mathrm{~h}$ with returning to control in $24 \mathrm{~h}$. Much more interesting were the SQDG changes both through 4 and in $24 \mathrm{~h}$. In leaves this compound accumulation up to $150 \%$ of control was observed in $4 \mathrm{~h}$ and changed by drastic fall (twice comparing to control) in $24 \mathrm{~h}$. But most interesting was the fact (taking into account that wounding was rendered as cutting off $1 \mathrm{~cm}$ of leaf apex) significant SQDG content increase (twice) in roots in both 4 and $24 \mathrm{~h}$. We consider this phenomenon to be an evidence of SQDG taking part in plant system response (unpublished results).
Infection. A few experiments suggest that infection can affect membrane lipids. In our experiments, a relative accumulation of SQDG in the total glycolipids in wheat plants infected by Puccinia graminis [34] and kidney bean plants infected by potato $x$ potexvirus (PXV) or tobacco mosaic (TMV) virus was observed. The latter phenomenon was confirmed by a significant increase of the SQDG/DGDG ratio (used because DGDG was the most stable component in the experiments) [64]. These changes could be useful for the plant if the action of SQDG in inhibiting viral development (and against DNA-polymerase and reverse transcriptase activity $[65,66])$, also apply to in vivo situations. On the other hand, it could be connected with oxidative stress accompanied the virus infection $[67,68]$. But in barley stripe mosaic virus strains and poa semilatent hordeivirus losses of MGDG, PG, SQDG and chlorophyll as well as relative increases in phosphatidylcholine, phosphatidylethanolamine and phosphatidylinositol contents were observed [69]. Thus, information presented argues that quality and/or relative content of SQDG changes in response to a stressor action.

Conclusions. Thus, analyzing information presented one could conclude that SQDG functions known to date are multiple. The quality and/or relative content of SQDG changes in response to a stress action. Concerning the interpretation of the phenomena observed at various type stress action we consider to take place two type of response - more general to the oxidative stress and specific - to the concrete stress factor action. Besides, we should keep in mind the necessity of consideration of two types of reaction taking place in photosynthesizing and non-photosynthesizing tissues. In photosynthesizing tissues it seems putative to assume availability of all structural and functional SQDG molecules peculiarities known for today to supply their taking part in adaptation reaction as cytochrome oxidase, $\mathrm{CF}_{1}, \mathrm{~F}_{1}$, ATPase regulators, protectors and stabilizing agents for $D_{1} / D_{2}$ dimers and LHC II $[50,70]$. Taking into account the SQDG localization on the native heterodimer $D_{1} / D_{2}$ surface [71], one could assume that it might hold monomers together as dimer [72]. Therefore it is not excluded that SQDG certain molecular specie accumulation can prevent RC PS II degradation. Function of the compound in nonphotosyn- 
thesizing tissues could be connected with negative charge domination requirement for univalent cation $\left(\mathrm{Na}^{+}\right.$and $\left.\mathrm{K}^{+}\right)$being necessary for lipoprotein complex stabilisation. Besides, the compound can realize ATPase and PL $\mathrm{A}_{2}$ activity regulation [73] both in photosynthetic and non-photosynthetic tissues. We assume also the possibility of the additional water amount capturing because of SQDG absorption in the space between the SQDG layers in membrane which intensity increases gradually when temperature is rising [74]. It could also inhibit the nonbilayer structure forming by means of making bilayer MGDG structure organization and takes part in the MGDG synthesis via regulation UDP-galactoso: diacylglycerol galactosyl transferase activity thus correcting MGDG/DGDG ratio in membrane $[75,76]$. A certain role SQDG plays in the processes of protein synthesized transport. It is important because of the enforced synthesis of a wide set of specific proteins during a stress action. The transit peptide inserts most efficiently in monolayers of PG, SQDG and MGDG suggesting that these lipid classes are mainly responsible for insertion into the target lipid of membrane [72]. But among all functions the main seems to be energetical one. In photosynthesizing tissues SQDG molecules stabilize F-ATPase, protect and stabilize D1/D2 dimers and LHC II [50, 70]. SQDG and the Rieske protein interaction in the cyt $b 6 f$ structures is also very important [77]. Photoinhibition arising at a stressor action induces degradation and cleavage of D1 protein of RC PS II [78]. However, SQDG localized on the surface of the native D1/D2 heterodimer might hold monomers together as a dimer $[71,72]$.

Thus, this lipid seems to be involved in the stress adaptation reactions and can be a unit of the adaptation mechanism chain.

\section{О. І. Косик, О. А. Оканенко, Н. Ю. Таран}

Рослинний сульфоліпід. III. Роль в адаптації

Резюме

Якісний $i$ відносний вміст сульфохіновозилдіацилгліцеролу (СХДГ) у рослинах змінюється відповідно до дії стресора. Різні чинники індукують два види відповіді: загальну - на окиснювальний стрес і спеиифічу - на конкретний стресовий фактор. Окрім того, два види відгуку спостерігаються у фотосинтезувальних і нефотосинтезувалиних тканинах. Молекули СХДГ беруть участь у реакиії адаптації як регулятори ичитохромок- сидази, $C F_{1}, F_{1}$ і АТРаз та як агенти, щуо стабілізують димери $D_{1} / D_{2}$ i LHC II. Наявність иієєї сполуки у нефотосинтезувальних тканинах може бути пов'язана з вимогою домінування негативного заряду одновалентного катіона $\left(\mathrm{Na}^{+}\right.$або $\left.\mathrm{K}^{+}\right)$для стабілізації ліпопротеїнового комплексу. Кількісні зміни вмісту СХДГ та ацильного складу відбуваються при дії як абіотичних, так $і$ біотичних стресорів.

Ключові слова: сульфоліпід, сульфохіновозилдіацилгліцерол, cmpec.

\section{О. И. Косык, А. А. Оканенко, Н. Ю. Таран}

Растительный сульфолипид. III. Роль в адаптации

Резюме

Качественное и относительное содержание растительного сульфохиновозилдиачилглицерола (СХДГ) изменяется в ответ на действие стрессоров. Разные стрессоры вызывают два вида ответа: более общий-на окислительный стресс и специфический - на действие конкретного фактора. Кроме того, два вида реакиии наблюдаются в фотосинтезируюших и нефотосинтезирующих тканях. Молекулы СХДГ участвуют в реакиии адаптации как регуляторы ичитохромоксидазы, $C F_{l}, F_{l}$, АТРаз и как стабилизируюшие агенты димеров $D_{1} / D_{2}$ и LHC II. Роль этого соединения в нефотосинтезирующих тканях может быть связана с необходимостью доминирования негативного заряда одновалентного катиона $\left(\mathrm{Na}^{+}\right.$или $\left.\mathrm{K}^{+}\right)$для стабилизации липопротеинового комплекса. Количественные изменения содержания СХДГ и ацильного состава происходят при действии как абиотических, так и биотических стрессоров.

Ключевые слова: сульфолипид, сульфохиновозилдиачилглииерол, стресс.

\section{REFERENCES}

1. Pearcy $R$. Effect of growth temperature on the fatty acid composition of the lipids in Atriplex lentiformis (Torr) Wats // Plant Physiol.-1978.-61, N 4.-P. 484-486.

2. Quartacci M. F., Pinzino C., Sgherri C., Navari-Izzo F. Lipid composition and protein dynamics in thylakoids of two wheat cultivars differently sensitive to drought // Plant Physiol.1995.-108, N 1.-P. 191-197.

3. Quinn P. J. The role of lipids in stability of plant membranes // Advances in Plant Lipid Research / Eds J. Sanches, E. Gerda-Olmedo, E. Martinez-Force.-Seville, Univ. Sevilla publ., 1998.-P. 361-366.

4. Taran N. The lipid composition of wheat leaves is an index of plant resistance // Advances in Plant Lipid Research / Eds J. Sanches, E. Gerda-Olmedo, E. Martinez-Force--Seville, Univ. Sevilla publ., 1998.-P. 517-520.

5. Blee E. Impact of phyto-oxylipins in plant defense // Trends Plant Sci.-2002.-7, N 7.-P. 315-321.

6. Harwood J. L. Environmental factors which can alter lipid metabolism // Progr. Lipid Res.-1994.-33, N 1-2.-P. 193202.

7. Harwood J. L. Recent environmental concerns and lipid metabolism // Plant Lipid Metabolism / Eds J.-C. Kader, P. Mazliak.-Dordrecht: Kluwer Acad. publ., 1995.-P. 361-368.

8. Asada K., Takahashi M., Tanaka K., Nakamo Y. Formation of active oxygen and its fate in chloroplasts // Biochemical and 
Medical Aspects of Active Oxygen / Eds O. Hayaishi, K. Asada.-Tokyo: Sc. Soc. press, 1977.-P. 45-63.

9. Alscher R. G., Donahue J. L., Cramer C. L. Molecular responses to reactive oxygen species: multifaceted changes in gene expression // Responses of Plant Metabolism to Air Pollution and Global Change / Eds L. J. de Kok, I. Stulen.Leiden: Backhuys publ., 1998.-P. 233-240.

10. Senaratna T., McKersie B. D., Stinson R. H. Simulation of dehydration injury to membranes from soybean axes by free radicals // Plant Physiol.-1985.-77, N 2.-P. 472-474.

11. Quartacci M. F., Navari-Izzo F. Water stress and free radical mediated changes in sunflower seedlings // J. Plant Physiol.1992.-139, N 5.-P. 621-625.

12. Navari-Izzo F., Quartacci M. F., Melfi D., Izzo R. Lipid composition of plasma membranes isolated from sunflower seedlings grown under water stress // Physiol. Plant.-1993.-87, N 4.-P. 508-514.

13. Sakaki T. Photochemical oxidants: toxicity // Responses of Plant Metabolism to Air Pollution and Global Change / Eds L. J. de Kok, I. Stulen.- Leiden: Backhuys publ., 1998.-P. 117129.

14. Sakaki T., Ohnishi J., Kondo N., Yamada M. Polar and neutral lipid changes in spinach leaves with ozone fumigation. Triacylglycerol synthesis from polar lipids // Plant Cell Physiol.-1985.-26, N 2.-P. 253-262.

15. Sakaki T., Tanaka K., Yamada M. General metabolic changes in leaf lipids in response to ozone // Plant Cell Physiol.-1994.-35, N 1.-P. 53-62.

16. Berge J. P., Debiton E., Dumay J., Durand P., Barthomeuf C. In vitro anti-inflammatory and anti-proliferative activity of sulfolipids from the red alga Porphyridium crurentum // J. Agric. Food Chem.-2002.-50, N 21.-P. 6227-6232.

17. Taran N., Batsmanova L., Okanenko A. Oxidation stress induce leaf lipid changes $/ / 16^{\text {th }}$ Int. Plant Lipid Symp. (1-4 June 2004 Budapest, Hungary).-Budapest, 2004.-P. 95-101.

18. Norman H. A., Mischke C. F., Allen B., Vincentt J. S. Semipreparative isolation of plant sulfoquinovosyldiacylglycerols by solid phase extraction and HPLC procedures // J. Lipid Res.-1996.-37, N 6.-P. 1372-1376.

19. Harwood J. L. Sulfolipids // The Biochemistry of Plants / Eds P. K. Stumpf, E. E. Conn.-New York: Acad. press, 1980.P. 301-320.

20. Mock T., Kroon B. M. A. Photosynthetic energy conversion under extreme conditions-II: The significance of lipids under light limited growth in Antarctic sea ice diatoms // Phytochemistry.-2002.-61, N 1.-P. 53-60.

21. Minoda A., Sonoike K., Nozaki H., Okada K., Sato N., Tsuzuki M. Contribution of SQDG in photosystem II of Chlamydomonas reinhardtii. PS2001// Proc. of the $12^{\text {th }}$ Int. Congr. on Photosynthesis (Brisbane, Australia, 2001).-Brisbane: CSIRO publ., 2001.-S5-039.

22. Khotimchenko S. V., Yakovleva I. M. Lipid composition of the red alga Tichocarpus crinitus exposed to different levels of photon irradiance // Phytochemistry.-2005.-66, N 1.-P. 7379.

23. Sato N., Murata N., Miura G., Veta N. Effect of growth temperature on lipid and fatty acid composition in the blue-green algae Anabaena variabilis and Anacystis nidulans // Biochim. et Biophys. Acta.-1979.-572, N 1.-P. 19-28.

24. Sato N., Murata N. Temperature shift-induced response in lipid in the blue-green algae Anabaena variabilis. The central role of diacyl monogalactosyl glycerol in thermoadaptation // Biochim. et Biophys. Acta.-1980.-619, N 2.-P. 353-366.
25. Wada H., Murata N. Membrane lipids in Cyanobacteria // Lipids in Photosynthesis: Structure, Function and Genetics. Advances in Photosynthesis 6 / Eds P.-A. Siegenthaler, N. Murata.-Amsterdam: Kluwer Acad. publ., 1998.-P. 83-101.

26. Quoc K. P., Dubacq J. P. Effect of growth temperature on the biosynthesis of eukaryotic lipid molecular species by the Cyanobacterium Spirulina platensis // Biochim. et Biophys. Acta.-1997.-1346, N 3.-P. 237-246.

27. Okanenko A., Protsenko D. Apple-tree shoot bark lipid composition dynamics // Physiologiya i Biohimiya Kulturnyh Rastenij.-1977.-9, N 1.-P. 80-85 (in Russian).

28. Oquist $G$. Seasonally induced changes in acyl lipids and fatty acids of chloroplast thylakoids of Pinus silvestris // Plant Physiol.-1982.-69, N 4.-P. 869-875.

29. Orr G., Raison J. Compositional and thermal properties of thylakoid polar lipids of Nerium oleander L. in relation to chilling sensitivity // Plant Physiol.-1987.-84, N 1.-P. 8892.

30. Okanenko A., Taran N. High temperature and water deficit action upon winter wheat chloroplast lipid composition // Factori sredi i organizatsiya vtorichnogo processa photosynteza / Ed. L. K. Ostrovskaya.-Kiev: Nauk. Dumka, 1989.P. 120-126 (in Russian).

31. Murata N., Yamaya J. Temperature-dependent phase behavior of phosphatidyl glycerols from chilling-sensitive and chilling-resistant plants // Plant Physiol.-1984.-74, N 4.P. 1016-1024.

32. KenrickJ., Bishop D. The fatty acid composition of phosphatidylglycerol and sulfoquinovosyl diacylglycerol of higher plants in relation to chilling sensitivity // Plant Physiol.1986.-81, N 4.-P. 946-948.

33. Okanenko A., Taran N., Musienko M. The heat and water stress effect on photosynthetic tissue lipid content // Botany and Mycology for the Next Millennium / Ed. S. Wasser.Kyiv: NASU, 1996.-P. 272-281.

34. Taran N., Okanenko A., Musienko M. Sulfolipid reflects plant resistance to stress-factor action // Biochem. Soc. Trans.2000.-28, N 6.-P. 922-924.

35. Pancratova $S$., Karimova $F$. Irrigation influence upon water exchange and winter rye leaf lipid composition.-Kazan, Deponed VINITY, 1984.-N 5537-84 Dep.-7 p. (in Russian).

36. Okanenko A., Taran N. Impact of heat stress on cereal lipid composition // Responses of Plant Metabolism to Air Pollution and Global Change / Eds L. J. de Kok, I. Stulen.Leiden: Backhuys publ., 1998.-P. 391-394.

37. Taranto P. A., Keenan T. W., Potts M. Rehydration induces rapid onset of lipid biosynthesis in desiccated Nostoc commune (Cyanobacteria) // Biochim. et Biophys. Acta.1993.-1168, N 2.-P. 228-237.

38. Ivanova A., Nechev J., Evstatieva L., Popov S., Stefanov K. Lipid composition of Calystegia soldanella - a halophytic plant from bulgarian black sea coast // Bulg. J. Plant Physiol.-2003.-Special Issue.-P. 394.

39. Hernandez J. A., Olmos E., Corpas F. J., Sevilla F., del Ryo L. A. Salt-induced oxidative stress in chloroplast of pea plants // Plant Sci.-1995.-105, N 2.-P. 151-167.

40. Hernandez J. A., Jimenez A., Mullineaux P. M., Sevilla F. Tolerance of pea (Pisum sativum L.) to long-term salt stress is associated with induction of antioxidant defenses // Plant Cell Environ.-2000.-23, N 8.-P. 853-862.

41. Gosset D. R., Banks S. W., Millhollon E. P., Lucas M. C. Antioxidant response to $\mathrm{NaCl}$ stress in a control and an $\mathrm{NaCl}$-tolerant cotton cell line grown in the presence of 
paraquat, buthionine sulfoximine, and exogenous glutathione // Plant Physiol.-1996.-112, N 2.-P. 803-809.

42. Hernandez J. A., Ferrer M. A., Jimenez A., Barcely A. R., Sevilla $F$. Antioxidant systems and $\mathrm{O}_{2}{ }^{-} / \mathrm{H}_{2} \mathrm{O}_{2}$ production in the apoplast of pea leaves. Its relation with salt-induced necrotic lesions in minor veins // Plant Physiol.-2001.-127, N 3.-P. 817-831.

43. Savouret A., Thorin D., Davey M., Hua X. J., Mauro S., Van Montagu M., Inzet D., Verbruggen N. NaCl and $\mathrm{CuZnSO}_{4}$ treatments trigger distinct oxidative defense mechanism in Nicotiana plumbaginifolia L. // Plant Cell Environ.-1999.22, N 4.-P. 387-396.

44. Allakhverdiev S. I., Nishiyama Y., Suzuki I., Tasaka Y., Murata N. Genetic engineering of the unsaturation of fatty acids in membrane lipids alters the tolerance of Synechocystis to salt stress // Proc. Nat. Acad. Sci. USA.-1999.-96, N 10.P. 5862-5867.

45. Deshnium P., Los D. A., Hayashi H., Mustardy L., Murata N. Transformation of Synechococcus with a gene for choline oxidase enhances tolerance to salt stress // Plant Mol. Biol.-1995.-29, N 5.-P. 897-907.

46. Muller M., Santarius K. A. Changes in chloroplast membrane lipids during adaptation of barley to extreme salinity // Plant Physiol.-1978.-62, N 3.-P. 326-329.

47. Kuiper P. J. C., Kahr M., Stuiver C. E. E., Kylin A. Lipid composition of whole roots and $\mathrm{Ca}^{2+}, \mathrm{Mg}^{2+}$-activated adenosine triphosphatases from wheat and oat as related to mineral nutrition // Physiol. Plant.-1974.-32, N 1.-P. 3336.

48. Kylin A., Kahr M. The effect of magnesium and calcium ions on adenosine triphosphatases from wheat and oat roots at different pH // Physiol. Plant.-1973.-28, N 3.-P. 452-457.

49. Stuiver C. E. E., de Kok L. J., Santers J. M. O., Kuiper P. J. C. The effect of $\mathrm{Na}_{2} \mathrm{SO}_{4}$ on the lipid composition of sugar beet plants // Z. Pflanzenphysiol.-1984.-114, N 2.-P. 187-191.

50. Pick U., Gounaris K., Weiss M., Barber J. Tightly bound sulfolipids in chloroplast $\mathrm{CF}_{0}-\mathrm{CF}_{1} / /$ Biochim. et Biophys. Acta.-1985.-808, N 3.-P. 415-420.

51. Huflejt M. E., Tremolieres A., Pineau B., Lang J. K., Hatheway J., Packer L. Changes in membrane lipid-composition during saline growth of the fresh-water Cyanobacterium synechococcus-6311 // Plant Physiol.-1990.-94, N 4.P. $1512-1521$.

52. Lattanzio V. M. T., Corcelli A., Mascolo G., Oren A. Presence of two novel cardiolipins in the halophilic archaeal community in the crystallizer brines from the salterns of Margherita di Savoia (Italy) and Eilat (Israel) // Extremophiles.-2002.-6, N 6.-P. 437-444.

53. Zhang H. X., Hodson J. N., Williams J. P., Blumwald E. Engineering salt-tolerant Brassica plants: Characterization of yield and seed oil quality in transgenic plants with increased vacuolar sodium accumulation // Proc. Nat. Acad. Sci. USA.2001.-98, N 22.-P.12832-12836.

54. Ramani B., Papenbrock J., Schmidt A. Connecting sulfur metabolism and salt tolerance mechanisms in the halophytes Aster tripolium and Sesuvium portulacastrum // Trop. Ecol.2004.-45, N 1.-P. 173-182.

55. Ramani B., Zorn H., PapenbrockJ. Quantification and fatty acid profiles of sulfolipids in two halophytes and a glycophyte grown under different salt concentrations // Z. Naturforsch. Sect. C.-2004.-59, N 11/12.-P. 835-842.

56. Bloem E., Riemenschneider A., Volker J., Papenbrock J., Schmidt A., Salac I., Haneklaus S., Schnug E. Sulphur supply and infection with Pyrenopeziza brassica influence L- cysteine desulfhydrase activity in Brassica napus L. // J. Exp. Bot.-2004.-55, N 406.-P. 2305-2312.

57. Pyurko O. Ye., Okanenko O. A., Taran N. Yu., Musienko M. $M$. Salt tolerance and plant sulpholipid // Visnyk (Herald) of Kyiv National University. Biology.-2002.-38.-P. 34-36 (in Ukrainian).

58. Harwood J. L. Membrane lipids in algae // Lipids in Photosynthesis: Structure, Function and Genetics. Advances in Photosynthesis 6 / Eds P.-A. Siegenthaler, N. Murata.-Amsterdam: Kluwer Acad. publ., 1998.-P. 53-64.

59. Youssef N. B., Zarrouk M., Daoud D., Lemal F., Ouariti O., Ghorbal M. H., Cherif A. Membrane lipid changes in Brassica napus induced by cadmium chloride // Advances in Plant Lipid Research / Eds J. Sanches, E. Gerda-Olmedo, E. Martinez-Force.-Seville: Univ. Sevilla publ., 1998.-P. 534-537.

60. Okanenko A., Taran N., Kosyk O. Sulphoquinovosyldiacylglycerol and adaptation syndrome // Advantes Research of Plant Lipids: Proc. of the $15^{\text {th }}$ Int. Symp. on Plant Lipid. (Japan).-Okazaki: Kluwer Acad. publ., 2003.-P. 361-364.

61. Sato N., Hagio M., Wada H., Tsuzuki M. Environmental effects on acidic lipids of thylakoid membranes // Biochem. Soc. Trans.-2000.-28, N 6.-P. 912-914.

62. Guschina I. A., Harwood J. L. Lipid metabolism in the moss Rhytidiadelphus squarrosus (Hedw) Warnst. from lead-contaminated and non-contaminated populations // J. Exp. Bot.2002.-53, N 368.-P. 455-463.

63. Orozco-Cardenas M., Ryan C. A. Hydrogen peroxide is generated systemically in plant leaves by wounding and systemin via the octadecanoid pathway // Proc. Nat. Acad. Sci. USA.1999.-96, N 11.-P. 6553-6557.

64. Senchugova N. A., Taran N. Yu., Okanenko A. A. Virus impact upon bean photosynthesising tissue lipid composition // Arch. Phytopath. Pflanz.-1999.-32, N 6.-P. 471-477.

65. Ohta K., Mizushina Y., Hirata N., Takemura M., Sugawara F., Matsukage A., Yoshida S., Sakaguchi K. Sulfoquinovosyldiacylglycerol, KM043, a new potent inhibitor of eukaryotic DNA polymerases and HIV-reverse transcriptase type I from a marine red alga, Gigartina tenella // Chem. Pharm. Bull. (Tokyo).-1998.-46, N 4.-P. 684-686.

66. Ohta K., Hanashima S., Mizushina Y., Yamazaki T., Saneyoshi M., Sugawara F., Sakaguchi K. Studies on a novel DNA polymerase inhibitor group, synthetic sulfoquinovosylacylglycerols: inhibitory action on cell proliferation // Mutat. Res.-Genet. Toxicol. Environ. Mutagen.-2000.-467, N 2.P. 139-152.

67. Fodor J., Hideg E., Kecskes A., Kiraly Z. In vivo detection of tobacco mosaic virus-induced local and systemic oxidative burst by electron paramagnetic resonance spectroscopy // Plant Cell Physiol.-2001.-42, N 7.-P. 775-779.

68. Hernandez J. A., Talavera J. M., Martynez-Gomez P., Dicenta $F$., Sevilla $F$. Response of antioxidant enzymes to plum pox virus in two apricot cultivars // Physiol. Plant.-2001.-111, N 3.-P. 313-321.

69. Adam A., Nagy P. D. Variations of membrane polar lipids of barley leaves infected with three strains of barley stripe mosaic virus and with poa semilatent virus // Plant Sci.1989.-61, N 1.-P. 53-59

70. Livn A., Racker E. Partial resolution of the enzymes catalyzing photophosphorylation. V. Interaction of coupling factor I from chloroplasts with ribonucleic acid and lipids // J. Biol. Chem.-1969.-244, N 5.-P. 1332-1338.

71. Vijayan P., Routaboul J.-M., Browse J. A genetic approach to investigating membrane lipid structure and photosynthetic function // Lipids in Photosynthesis: Structure, Function and 
Genetics. Advances in Photosynthesis 6 / Eds P.-A. Siegenthaler, N. Murata.-Amsterdam: Kluwer Acad. publ., 1998.-P. 263-285.

72. Kruijff B. de, Pilon R., Hof R., van't., Demel R. Lipid-protein interactions in chloroplast protein import // Lipids in Photosynthesis: Structure, Function and Genetics. Advances in Photosynthesis 6 / Eds P.-A. Siegenthaler, N. Murata.Amsterdam: Kluwer Acad. publ., 1998.-P. 191-208.

73. Vishwanath B. S., Eichenberger W., Frey F. J., Frey B. M. Interaction of plant lipids with $14 \mathrm{kDa}$ phospholipase A2 enzymes // Biochem. J.-1996.-320, N 1.-P. 93-99.

74. Shipley G. G., Green J. P., Nichols B. W. The phase behavior of monogalactosyl, digalactosyl, and sulphoquinovosyl diglycerides // Biochim. et Biophys. Acta.-1973.-311, N 4.P. 531-544.

75. Coves J., Joyard J., Douce R. Lipid requirement and kinetic studies of solubilized UDP-galactose: diacylglycerol galactosyltransferase activity from spinach chloroplast envelope membranes // Proc. Nat. Acad. Sci. USA.-1988.-85, N 11.P. 4966-4970.

76. Li L., Karlsson O. P., Wieslander A. Activating amphiphiles cause a conformational changes of the 1,2-diacylglycerol transferase from Acholeplasma laidlavii membranes according to proteolytic digestion // J. Biol. Chem.-1997.-272, N 47.-P. 29602-29606.

77. De Vitry C., Ouyang Y., Finazzi G., Wollman F.-A., Kallas T. The chloroplast Rieske iron-sulfur protein at the crossroad of electron transport and signal transduction // J. Biol. Chem.2004.-279, N 43.-P. 44621-44627.

78. Kettunen R., Tyystjarvi E., Aro E. M. Degradation pattern of photosystem II reaction center protein D1 in intact leaves. The major photoinhibition-induced cleavage site in D1 polypeptide is located amino terminally of the DE loop // Plant Physiol.-1996.-111, N 4.-P. 1183-1190.

УДК 755.121

Надійшла до редакції 15.12.07 